\title{
Biological, Physical, and Molecular Properties of a Papaya lethal yellowing virus Isolate
}

\author{
Aline K. Q. Nascimento, J. Albersio A. Lima, Ana L. L. Nascimento, and Evando A. Beserra, Jr., Federal Uni- \\ versity of Ceará, Plant Virus Laboratory, P.O. Box 6046, 60451-970, Fortaleza, CE, Brazil; and Dan E. Purcifull, \\ 3106 N.W. First Avenue, Gainesville, FL 32607
}

\begin{abstract}
Nascimento, A. K. Q., Lima, J. A. A., Nascimento, A. L. L., Beserra, E. A., Jr., and Purcifull, D. E. 2010. Biological, physical, and molecular properties of a Papaya lethal yellowing virus isolate. Plant Dis. 94:1206-1212.

Papaya (Carica papaya) is an important tropical fruit crop in northeastern Brazil. Lethal yellowing is a disease caused by Papaya lethal yellowing virus (PLYV) that occurs only in northeastern Brazil. The symptoms are characterized by progressive leaf yellowing and greenish circular spots on the fruits. The virus has isometric particles $(30 \mathrm{~nm})$, genomic single-stranded (ss)RNA $\left(1.6 \times 10^{6} \mathrm{Da}\right)$, and a coat protein with a single component $(35 \mathrm{kDa})$. Although no biological vector has been confirmed, the virus is spreading every year. In the present study, an isolate of the virus was characterized biologically, serologically, physically, and molecularly, and its survival in dried tissue was evaluated. Approximately $309.5 \mathrm{mg}$ of virus was purified per kilogram of infected papaya leaves, and a high-titer polyclonal antiserum $(1: 1,024,000)$ was obtained from an immunized rabbit. The virus was detected in dried roots and leaves maintained up to 120 days. Its physical properties were thermal inactivation point $\left(80^{\circ} \mathrm{C}\right)$, longevity in vitro (60 days), and dilution end point $\left(10^{-6}\right)$. The virus was inactivated in leaves and roots eradicated from infected plants when they were submitted to a solarization period of 12 days, but maintained its infectivity when leaves and roots were maintained over the soil at natural conditions for 32 days. Among 58 plant species from 13 botanical families, the PLYV isolate infected only $C$. papaya, Jacaratia heterophylla, J. spinosa, Vasconcella cauliflora, V. quercifolia, and V. monoica, all from the family Caricaceae. A fragment of 1,098 nt of the virus isolate, corresponding to the $3^{\prime}$ replicase (RdRp) and $5^{\prime}$ coat protein $(\mathrm{CP})$ cistron, was cloned and sequenced. Phylogenetic analysis of the RdRp nucleotide sequences indicated some similarity of PLYV with members of the genus Sobemovirus.
\end{abstract}

Brazil has excellent conditions for tropical fruit crop production, including papaya (Carica papaya L.). Brazil is the highest producer of this crop in the world, with an estimated production of $1,812,000 \mathrm{t}$ in 2007 in a cultivated area close to 35,000 ha (11). In northeastern Brazil, tropical fruit production has been the agribusiness activity with the greatest growth in the last 10 years, and papaya production contributed most to this intensive growth, being responsible for an average production of $1,093,838 \mathrm{t}$ in 2007 (11). Unfortunately, several factors affect papaya productivity, mainly infectious diseases, especially those caused by viruses, which have been responsible for great losses in the crop countrywide $(1,4,17,20,21,28,30,39)$. The most important viruses that infect papaya in northeastern Brazil are Papaya ringspot virus (PRSV), family Potyviridae, genus Potyvirus (17); Papaya lethal yellowing

Corresponding author: J. Albérsio A. Lima E-mail: albersio@ufc.br

Accepted for publication 22 June 2010.

doi:10.1094/PDIS-11-09-0733

C) 2010 The American Phytopathological Society virus (PLYV), possible family Sobemoviridae, genus Sobemovirus (33); and Papaya meleira virus (PMeV), which is still being characterized to be taxonomically classified by the ICTV (23).

The disease caused by PLYV has been detected only in northeastern Brazil, and it was first identified in the State of Pernambuco (22), followed by Bahia (38), Rio Grande do Norte (26), Ceará (19), and Paraíba (6). The disease has become a serious problem for papaya producers in the region because of its serious damage in crop production and its increasing dispersion throughout the orchards in northeastern Brazil (5,13,14,19-21). The virus causes serious symptoms that begin with a progressive leaf yellowing in the third superior part of the plant canopies, which appear on the fruits which turn yellowish when the fruits are ripening $(5,21,32)$. Inoculated young plants show mosaic, leaf distortion, and yellowing. The PLYV does not have a known natural biological vector, but it is readily transmitted by human actions, including contaminated hands, agricultural tools, soil, and irrigation water $(5,21,32)$. Transmission studies indicated that the virus is neither transmitted in a nonpersistent manner by Myzus persicae wilt and finally die. Greenish circular spots
Sulzer, nor by Diabrotica bivitulla Kirke and $D$. speciosa Kirke $(13,14,19,33)$. The virus was not transmitted by seed from infected papaya fruits, although it was serologically detected on the seed surface but not in the embryo (5).

The PLYV has isometric particles that are $30 \mathrm{~nm}$ in diameter, with singlestranded (ss)RNA of $1.6 \times 10^{6} \mathrm{Da}$, and the coat protein is formed by a single protein component of ca. $35 \mathrm{kDa}(13,14)$. Molecular studies revealed $51 \%$ homology with polymerase and VPg nucleotide sequences with viruses from the family Sobemoviridae and only $39 \%$ with viruses in the family Tombusviridae, indicating the possibility of the virus to be included in the family Sobemoviridae, genus Sobemovirus (34).

In the present paper, an isolate of PLYV was biologically, serologically, physically, and molecularly characterized, and its survival properties in dried tissues of infected papaya plants were determined.

\section{MATERIALS AND METHODS}

Papaya orchard survey, virus isolation, and host range. Papaya orchards from the main production centers of the State of Ceará were surveyed for the presence of PLYV. Leaf and fruit samples with virus symptoms or suspicion of virus symptoms were collected and taken to the Plant Virus Laboratory at the Federal University of Ceará to be processed and tested by indirect enzyme-linked immunosorbent assay (ELISA) against antiserum for PLYV and PRSV. Samples were collected from the following papaya production centers: Acaraú (samples from 60 plants), Cariré (26 plants), Curupati (50 plants), Jaguaribara (64 plants), Limoeiro do Norte (100 plants), Marco (280 plants), Mauriti (20 plants), Mombaça (10 plants), Quixeramubim (20 plants), Quixeré (97 plants), and Varjota (118 plants). PLYV isolates were obtained from infected papaya leaves and fruits collected in the following counties from the State of Ceará: Fortaleza, Horizonte, Limoeiro do Norte, Marco, Paraipaba, and Quixeré. All the virus isolates were maintained in young papaya, under greenhouse conditions, free from insects. The plants were periodically tested for the presence of PLYV and absence of PRSV by indirect ELISA. Considering the new center of papaya production in Marco County, the PLYV isolate obtained in that region $\left(\mathrm{PLYV}_{\mathrm{M}}\right)$ was selected for further 
specific studies including host range, virus purification, antiserum production, and molecular and physical properties.

Plant species from the following families were inoculated with leaf extracts from papaya systemically infected with PLYV $\mathrm{V}_{\mathrm{M}}$ : Amaranthaceae: Gomphrena globosa L.; Asteraceae: Helianthus annuus L. and Lactuca sativa L.; Apiaceae: Daucus carota L.; Brassicaceae: Brassica oleracea L.; Caricaceae: Carica papaya L. 'Sunrise solo', 'Improved Sunrise solo', 'Tainung $\mathrm{n}^{\circ}$ 1', 'Hawaii', 'Bom', and 'Caiano'; Jacaratia heterophylla, J. spinosa Aublet A. DC., Vasconcella cauliflora (Jacq.) A. DC., V. quercifolia Jacq., and V. monoica (Desf.) A. DC.; Chenopodiaceae: Chenopodium amaranticolor Coste \& Reyn., $C$. murale L., and C. quinoa Willd.; Cucurbitaceae: Citrullus lanatus (Thunb.) Mansf., Cucumis melo L., C. anguria Forsk., C. metuliferus E. May, C. sativus L., Cucurbita ecuadorensis Cutles \& Whitaker, $C$. martinezzi L.H. Bailey, C. moschata Duch \& Reyn., C. pepo L., Lagenaria vulgaris Ser., Luffa cylindrica (L.) M.J. Roem, and L. operculata L.; Gramineae: Zea mays L.; Leguminosae: Cassia tora L., Centrosema brasilianum Benth., $C$. angustifolium (H.B.K.) Benth., C. pascuorum Mart., Clitoria ternatea L., Crotalaria striata L., Glycine max L., Galactia striata (Jacq.) Urb., Leucaena leucocephala (Lam.) de Wit, Macroptilium lathyroides (L.) Urb., M. atropurpureum (OC) Urb., Mimosa caesalpinoidae Benth., Macrotyloma axillare (E. Mey.) Verdc., Phaseolus vulgaris L., Rhynchosia mimosa L., Senna occidentalis L. Irw. Et. Barn., Vigna unguiculata (L.) Walp.; Malvaceae: Gossypium arboreum L., G. hirsutum L., and G. barbadense L.; Passifloraceae: Passiflora edulis Sims; Pedaliaceae: Sesamum indicum D.C.; Solanaceae: Capsicum annuum L., C. frutescens L., Datura stramonium L., Lycopersicon esculentum Mill., Nicotiana benthamiana Domin., N. glutinosa L., N. clevelandii Gray, N. tabacum L., and Solanum melongena Wall. All inoculated plants, including those that did not show any symptoms, were tested by indirect ELISA against the PLYV antiserum 25 days after inoculation, using leaves above the point of inoculation.

Virus purification. The $\operatorname{PLYV}_{M}$ was propagated in papaya and purified from systemically infected leaves showing yellowing and mosaic 30 days after inoculation according to Lima et al. (18). Leaves were ground in a blender in the presence of potassium phosphate buffer $0.1 \mathrm{M}, \mathrm{pH} 7.5$, containing $0.5 \%$ sodium sulfite, and the extract obtained was strained through double cheesecloth. The extract was clarified with $8 \% n$-butanol followed by centrifugation of $10,000 \times g$ for $10 \mathrm{~min}$. The virus was precipitated from the supernatant with $8 \%$ polyethylene glycol 6,000 (PEG) and $4 \%$ sodium chloride followed by a centrifugation at $10,000 \times g$ for $10 \mathrm{~min}$. The
PEG precipitation process was repeated twice and the final virus precipitate was resuspended and submitted to a high-speed centrifugation of $120,000 \times g$ for $2 \mathrm{~h}$. The pellet was resuspended in $3.0 \mathrm{ml}$ of Tris buffer $0.002 \mathrm{M}, \mathrm{pH} 8.2$, analyzed in a spectrophotometer, used for infectivity assays to healthy papaya, and used for antiserum production. To estimate the virus concentration, the ultraviolet extinction coefficient of 5.8 determined for Southern bean mosaic virus (SBMV), the type member of the genus Sobemovirus, was used (M. K. Brakke, unpublished data).

Polyacrylamide gel electrophoresis of viral protein. The $\mathrm{PLYV}_{\mathrm{M}}$ proteins were separated by sodium dodecyl sulfatepolyacrylamide gel electrophoresis (SDSPAGE) on $12 \%$ Tris- $\mathrm{HCl}$ gels according to Weber \& Osborn (40) as modified by Hiebert \& McDonald (10). Molecular weight markers were used as standards, and after electrophoresis, the gel was stained with bromophenol blue.

Polyclonal antiserum production. A New Zealand rabbit was immunized with the PLYV $_{M}$ purified preparation, using three weekly injections. In each immunization, an aliquot of $500 \mu \mathrm{l}$ from the purified virus preparation emulsified with an equal volume of Freund incomplete adjuvant was injected in the foot pad of the animal. Fifteen days after the last injection, the rabbit was bled for antiserum production according to Purcifull and Batchelor (27). The antiserum was evaluated by indirect ELISA and Ouchterlony double-diffusion tests, and stored at $-20^{\circ} \mathrm{C}$.

Indirect ELISA. The ELISAs were performed according to Mowat and Dawson (24), and the results were considered to be positive reactions when the absorption values were more than two and a half times the average values obtained for the extracts from healthy papaya used as a control. The antiserum titer was determined in indirect ELISA using the following antiserum dilutions: 1:500, 1:1,000, $1: 2,000, \quad 1: 4,000, \quad 1: 8,000, \quad 1: 16,000$, $1: 32,000,1: 64,000,1: 128,000,1: 256,000$, $1: 512,000$, and $1: 1,024,000$. The antiserum reactivity was also evaluated against the extract from infected papaya in the following dilutions: $1: 500$ to $1: 1,024,000$, using the antiserum in dilutions of 1:8,000 and $1: 16,000$.

Immunodiffusion. To evaluate the antiserum by a less sensitive serological test, it was also tested in agar gel containing $0.8 \%$ Noble Agar and $1.0 \%$ sodium azide. The antiserum titer was determined using the following antiserum dilutions: 1:2, 1:4, $1: 8,1: 16,1: 32,1: 64,1: 128,1: 256,1: 512$, $1: 1,024$, and $1: 2,048$ against the extract from infected plants prepared in dilutions of $1: 5$ and 1:10. Additional tests were performed with the antiserum diluted to $1: 8$ and 1:16 against extracts from infected papaya diluted to $1: 2$ to $1: 1,024$.
Stability of virus in sap. The stability of PLYV $\mathrm{V}_{\mathrm{M}}$ in sap was evaluated by determining its longevity in vitro (LIV), thermal inactivation point (TIP), and dilution end point (DEP), using infected papaya as the source of virus and healthy young papaya as the indicator plant. As the virus does not have a known local lesion host, the physical properties were determined by inoculation of eight young papaya plants with each treatment. The TIP was estimated using the temperature range 45 to $90^{\circ} \mathrm{C}$, and the LIV was determined using the periods of $0,1,2,4,10,15,20,30,40$, 50 , and 60 days. The DEP was determined using the sap from infected plants diluted to $1: 10,1: 100,1: 1,000,1: 10,000$, and $1: 100,000$ in $0.1 \mathrm{M}$ potassium phosphate buffer, $\mathrm{pH} 7.5$.

Detection of virus in dried infected tissue and solarization for virus inactivation. The first part of this experiment was developed to evaluate how long the virus particles could survive in dried and dead infected plant tissues. One hundred grams of roots and $100 \mathrm{~g}$ of leaves of young papaya plants infected with PLYV $\mathrm{V}_{\mathrm{M}}$ were dried at room temperature, and at 10day intervals, 20 samples of $2.0 \mathrm{~g}$ of each kind of dried tissue were evaluated for the presence of active virus by inoculation of 20 healthy papaya plants, using one plant per sample, and tested for the PLYV presence by indirect ELISA.

To evaluate the solarization effects in the $\mathrm{PLYV}_{\mathrm{M}}$ inactivation in infected tissue after plant eradication, aerial parts and root system from 12 infected papaya plants were submitted to solarization by covering the tissues with transparent plastic. To avoid the temperature exchange, the plastic boards were covered with soil. Similar aerial and root tissues from 12 infected papaya plants were maintained over the soil at natural conditions. At 4-day intervals, 12 tissue samples from each of the leaves and roots maintained under the plastic and over the soil were tested by indirect ELISA and inoculated on healthy young papaya plants.

Isolation of virus RNA. Virus particles were concentrated from infected papaya plants according to Lane (16) and were resuspended in $500 \mu \mathrm{l}$ of $0.01 \mathrm{M}$ potassium phosphate buffer, pH 7.0. Viral RNA was extracted from $200 \mu \mathrm{l}$ of viral concentrate, with the addition of $50 \mu \mathrm{l}$ of RNA extraction buffer $(0.2 \mathrm{M}$ glycine, $0.2 \mathrm{M} \mathrm{NaCl}$, $0.02 \mathrm{M}$ EDTA, $\mathrm{pH}$ 9.5). This mixture was adjusted to $1.5 \%(\mathrm{wt} / \mathrm{vol}) \mathrm{SDS}$ and 100 $\mu \mathrm{g} / \mathrm{ml}$ Proteinase K (GibcoBRL) and then kept for $1.0 \mathrm{~h}$ at $37^{\circ} \mathrm{C}$. The RNA was extracted with one volume of phenol/ chloroform (1:1) and precipitated with 2.5 volumes of $100 \%$ ethanol. The pellet was washed with $70 \%$ (vol/vol) ethanol and resuspended in $20 \mu \mathrm{l}$ of DEPC (Diethyl pyrocarbonate)-treated, sterile water.

Molecular analyses of virus isolates. A viral genome fragment amplified by re- 
verse transcription-polymerase chain reaction (RT-PCR) from PLYV $\mathrm{P}_{\mathrm{M}}$ was cloned and sequenced. Total RNA from papayainfected leaves was extracted with Trizol Reagent (Gibco-BRL Life Technologies) according to the manufacturer's instructions. First strand cDNA was synthesized from viral RNA using the M-MLV Reverse Transcriptase (Promega) according to the manufacturer's instructions. Viral fragments corresponding to a portion of the RdRp and CP cistron were amplified by PCR using $2.0 \mu \mathrm{l}$ of cDNA, $2.5 \mu \mathrm{l}$ of enzyme buffer, $1.5 \mu \mathrm{l}$ of $25 \mathrm{mM} \mathrm{MgCl}_{2}, 1.0$ $\mu l$ of the deoxynucleotide mixture (0.01 M), 20 pmol of each primer, and 1 unit of DNA polymerase (Promega). PCR was carried out using PLYV-specific primers PLYV-1 (5' CTGAAGCGGATATTTCTGG $\left.3^{\prime}\right)$ and PLYV-2 (5' GTGTATGGCATA CAGTTATC $3^{\prime}$ ) (34), which directed the amplification of a fragment of approximately $1,098 \mathrm{nt}$ corresponding to part of $\mathrm{RdRp} / \mathrm{CP}$ gene sequences. PCR reactions consisted of 35 cycles of denaturing at $95^{\circ} \mathrm{C}$ for $1 \mathrm{~min}$, primer annealing at $45^{\circ} \mathrm{C}$ for $2 \mathrm{~min}$, and primer extension at $72^{\circ} \mathrm{C}$ for $1 \mathrm{~min}$, with a final extension at $72^{\circ} \mathrm{C}$ for $5 \mathrm{~min}$. The amplified product was visualized in a $1 \%$ agarose gel treated with ethidium bromide under ultraviolet light The amplified fragment was cloned using the pGEM-T Easy Vector System I (Promega) according to the manufacturer's instructions and was transformed into $E s$ cherichia coli JM109 competent cells. Recombinant plasmids were identified by enzymatic cleavage using EcoRI, and the viral insert was sequenced using the BigDye Terminator Cycle Sequencing Ready Reaction Kit (Perkin-Elmer) according to the manufacturer's instructions.
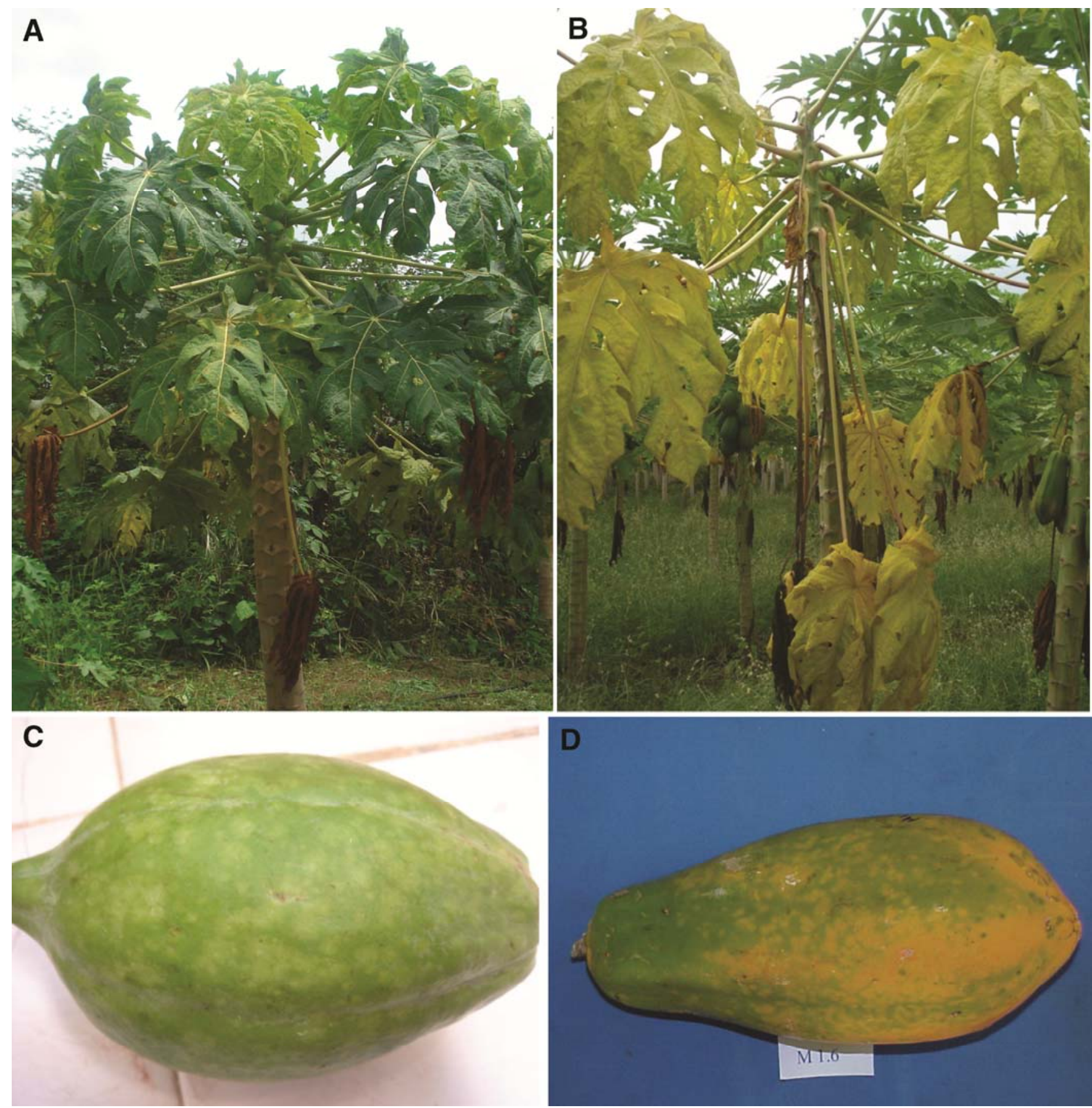

Fig. 1. Papaya (Carica papaya) 'Formosa' exhibiting symptoms caused by Papaya lethal yellowing virus (PLYV). A, A plant in a papaya orchard in the Marco County, State of Ceará, Brazil, exhibiting the first symptoms with a progressive leaf yellowing in the third superior part of the plant canopy. B, A plant showing advanced stage of yellowing of the leaves in the entire plant canopy. C, Green fruits with greenish circular spots. D, Mature fruit presenting yellowish circular spots. 
Phylogenetic analysis. The sequenced genome fragment of approximately $927 \mathrm{nt}$ corresponding to the RdRp gene sequenced from PLYV $\mathrm{V}_{\mathrm{M}}$ was compared with the nucleotide sequences of the following members of the genus Sobemovirus: Rice yellow mottle virus (RYMoV) (GenBank accession no. AM883054), Ryegrass mottle virus (RGMoV) (GenBank accession no. DQ481606), Sesbania mosaic virus (SeMV) (GenBank accession no. AY004291), Southern bean mosaic virus (SBMV) São Paulo strain (GenBank accession no. DQ875594), Subterranean clover mottle virus (SCMoV) (GenBank accession no. AY376453), and Turnip rosette virus (TRosV) (GenBank accession no. AY177608). Sequences were analyzed using the programs DNAMAN 4.0 (Lynnon BioSoft) and Blastn (www.ncbi.nlm. nih.gov/blast). The sequences were further aligned using the program Clustal W (www.ebi.ac.uk/clustalw), and the phylogenetic tree was constructed using the MEGA v. 4.0 program (15).

\section{RESULTS}

Papaya orchard survey, virus isolation, and host range. The $\mathrm{PLYV}_{M}$ obtained from naturally infected papaya (Fig. 1) was shown to be free from PRSV infection and caused very typical symptoms in inoculated papaya consisting of mosaic, leaf yellowing, and distortion. The serological survey confirmed the presence of PLYV in papaya orchards from several production centers of the State of Ceará. According to the serological survey, the virus was detected in different percentages of the papaya samples collected in orchards from the following locations: Acaraú (54 PLYV-infected plants from 60 plants sampled, or $90 \%)$, Curupati (16/50, $32 \%)$, Limoeiro do Norte (42/100, 42\%),

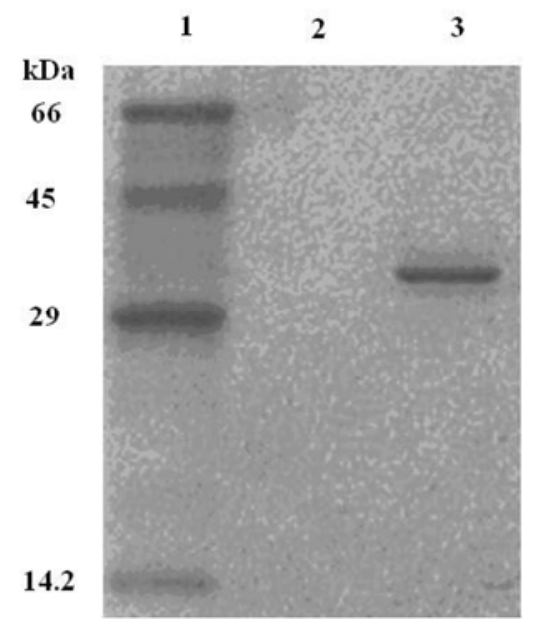

Fig. 2. Polyacrylamide gel electrophoresis analysis of sodium dodecyl sulfate-degraded purified preparation of Papaya lethal yellowing virus (PLYV). Lane 1, standard proteins of indicated molecular mass (in $\mathrm{kDa}$ ); lane 2, supernatant of virus purification; lane 3, PLYV purified preparation (1:10).
Marco (70/280, 25\%), Quixeramubim (5/20, 5\%), and Quixeré (32/97, 33\%). PLYV was also detected in mixed infection with PRSV in the orchards from Acaraú, Limoeiro do Norte, Marco, and Quixeré.

$\mathrm{PLYV}_{\mathrm{M}}$ infected all the papaya types tested, J. heterophylla, J. spinosa, V. cauliflora, V. monoica, and V. quercifolia, but did not cause infection in any of the other 52 plant species from 12 different plant families that were inoculated. All the symptom observations were confirmed by indirect ELISA. Among the four new hosts from the family Caricaceae, only $V$. monoica exhibited symptoms a week after virus inoculation. Although J. heterophylla, J. spinosa, and V. quercifolia did not present symptoms, PLYV $\mathrm{M}$ was detected by indirect ELISA 4 weeks after inoculation.

Virus purification. Purified $\mathrm{PLYV}_{M}$ showed a concentration of $12.38 \mathrm{mg}$ of nucleoprotein per $\mathrm{ml}$ of virus preparation, corresponding to $30.95 \mathrm{mg}$ of virus per $100 \mathrm{~g}$ of infected tissue, and was shown to be infective to papaya causing the typical PLYV symptoms. The ultraviolet absorption curve obtained for the virus had a maximum at $258 \mathrm{~nm}(=0.724)$ and a minimum at $244 \mathrm{~nm}(=0.503)$.

PAGE of viral protein. PAGE analysis of an SDS-degraded purified preparation of $\mathrm{PLYV}_{\mathrm{M}}$ revealed only one protein component with an estimated molecular weight of $34.7 \mathrm{kDa}$ (Fig. 2).

Polyclonal antiserum production. The antiserum obtained for $\mathrm{PLYV}_{\mathrm{M}}$ reacted specifically with PLYV-infected papaya in indirect ELISA and immunodiffusion, but not with PRSV and only weakly with healthy papaya. After its absorption with extracts from healthy papaya, the antiserum showed a titer of $1: 1,024,000$ in indi- rect ELISA and of 1:128 in immunodiffusion. The antiserum dilutions of 1:8,000 and $1: 16,000$ showed positive results in indirect ELISA against all the extract dilutions $(1: 10$ to $1: 1,024,000)$ prepared from infected papaya, and the best ELISA absorption value was observed at the 1:1,000 extract dilution.

Stability of the virus in sap. The physical properties determined for PLYV $\mathrm{V}_{\mathrm{M}}$ revealed a TIP of $80^{\circ} \mathrm{C}$, a LIV of 60 days, and a DEP between $10^{-5}$ and $10^{-6}$. The results also confirmed the high stability of the virus, considering that only a few plant viruses have a TIP between 75 and $90^{\circ} \mathrm{C}$.

Detection of virus in dried infected tissue and solarization for virus inactivation. The presence of PLYV $V_{M}$ was detected by serological and biological tests in the dried roots and leaves of infected papaya maintained at room temperature during the period that the tissues were evaluated (120 days), but virus detection by ELISA and its infectivity decreased with time. After 20 days, the virus was detected in $100 \%$ of the dried leaf and root samples tested by ELISA, and the level of $100 \%$ was maintained for the leaves after 40 days, but decreased to $80 \%$ for the roots. ELISA detection in the leaves remained high $(90 \%)$ up to 80 days, while in the roots the level decreased to $60 \%$ in the same period. At the end of the period of 120 days, ELISA detection in the leaves remained over $70 \%$, while the root level decreased to $20 \%$. Infectivity assays also confirmed the survival of the virus particles in dried infected tissues for 120 days. After 20 days, $60 \%$ of the plants inoculated with dried leaf samples and $50 \%$ of the plants inoculated with dried roots were infected, and after 60 days of storage, $40 \%$ of the plants inoculated with dried leaf and
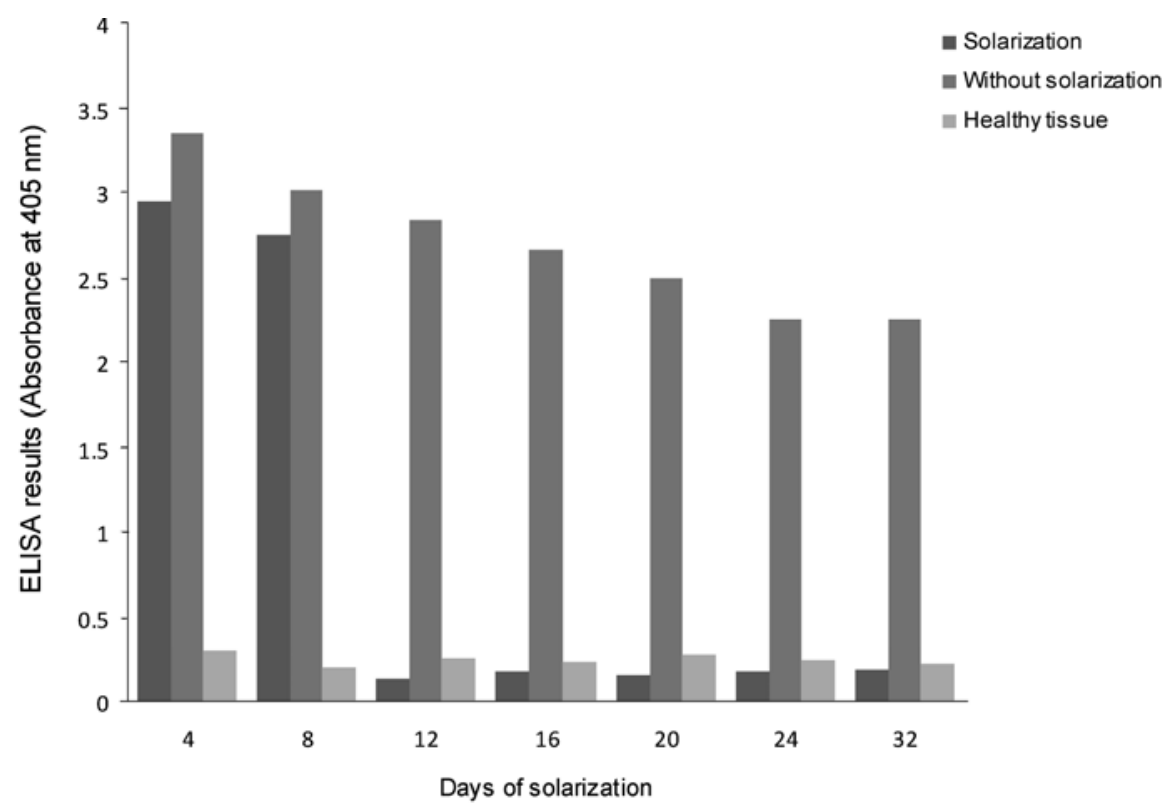

Fig. 3. Inactivation of Papaya lethal yellowing virus (PLYV) by solarization of leaves and roots removed from infected papaya (Carica papaya) plants as demonstrated by indirect enzyme-linked immunosorbent assay (ELISA). 
root tissues were infected. At the end of the experiment, $15 \%$ of the plants inoculated with leaf samples and 10\% inoculated with root samples were infected.

Solarization of PLYV $\mathrm{M}$-infected leaves and roots for a period of 12 days was sufficient to inactivate the virus. The presence of PLYV $\mathrm{V}_{\mathrm{M}}$ was not detected by ELISA in the papaya tissues 12 days after solarization, indicating virus degradation (Fig. 3). On the other hand, PLYV $\mathrm{V}_{\mathrm{M}}$ was detected by ELISA in the infected papaya tissues left in the soil submitted to natural sun radiation 32 days after the tissue had been eradicated from the plants (Fig. 3). The serological results were confirmed by biological tests when the tissues were inoculated in young, healthy papaya plants.

Genome size characterization and phylogenetic analysis. PLYV $\mathrm{V}_{M}$ nucleic acid was sensitive to digestion with RNase A but not with DNase (data not shown). The genomic RNA had a molecular size of ca. $5.0 \mathrm{~kb}$ (Fig. 4), and no other RNA or DNA species was observed in virion nucleic acid preparations. An amplified genome fragment of 1,098 nt, corresponding to the $3^{\prime} \mathrm{RdRp}$ and $5^{\prime} \mathrm{CP}$ citrons from

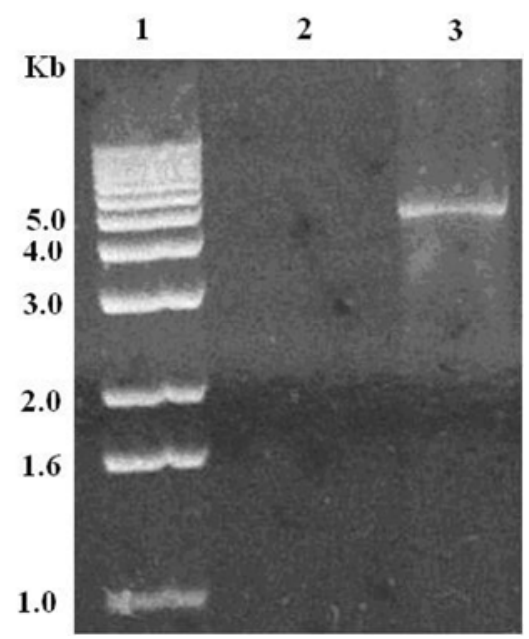

Fig. 4. Analysis of Papaya lethal yellowing virus (PLYV) RNA. Lane 1, RNA ladder with standards of indicated length in $\mathrm{Kb}$; lane 2, RNA isolated from healthy Carica papaya; lane 3, PLYV RNA isolated from purified virions and electrophoresed on a denaturing agarose gel and stained with ethidium bromide.
PLYV $_{M}$, was cloned and sequenced (GenBank accession no. GU066876). Comparison of nucleotide sequences of the PLYV $\mathrm{M}_{\mathrm{M}}$ RdRp cistron consisting of 927 nt revealed an identity level of $55 \%$ with RGMoV, $54 \%$ with TRosV, $52 \%$ with SeMV, and $52 \%$ with SBMV São Paulo strain (Table 1). A phylogenetic tree comparing partial nucleotide sequence of $\mathrm{PLYV}_{\mathrm{M}}$ to other sobemoviruses is presented in Figure 5. Tomato bushy stunt virus (TBSV), family Tombusviridae, genus Tombusvirus, which has virions morphologically similar to those of PLYV (14), was used as the outgroup virus species.

\section{DISCUSSION}

The serological detection of PLYVinfected papaya plants in several papaya orchards from different production centers of the State of Ceará confirmed that its dispersion is increasing every year in the state $(19,29)$. The host range studies confirmed that PLYV has a very restricted host range, thus far infecting only plant species in the family Caricaceae. Besides the papaya types, PLYV is also known to infect
V. cauliflora (2), which belongs to the family Caricaceae. The new hosts detected in the present research, J. heterophylla, $J$. spinosa, V. quercifolia, and V. monoica, also belong to the family Caricaceae. According to Badillo (3), J. heterophyla and $V$. monoica are not found growing naturally in Brazil, but J. spinosa and V. quercifolia are cultivated in central-west and south Brazil (9). Similarly, members of the genus Sobemovirus have relatively restricted host ranges, although some infect monocotyledons and dicotyledonous plants. The type member of the genus (SBMV) infects only plants in the family Leguminosae $(8,37)$.

The absorption ultraviolet spectrum and the ratios between the absorptions at 260 and $280\left(A_{260} / A_{280}\right)$ obtained for the purified virus preparation (1.80) was typical of viruses with polyhedral particles (25). The high virus concentration in the purified preparation indicates a very high level of virus in infected papaya, which was confirmed by the serological studies with antiserum produced in this research. The estimated mass of the single protein com-

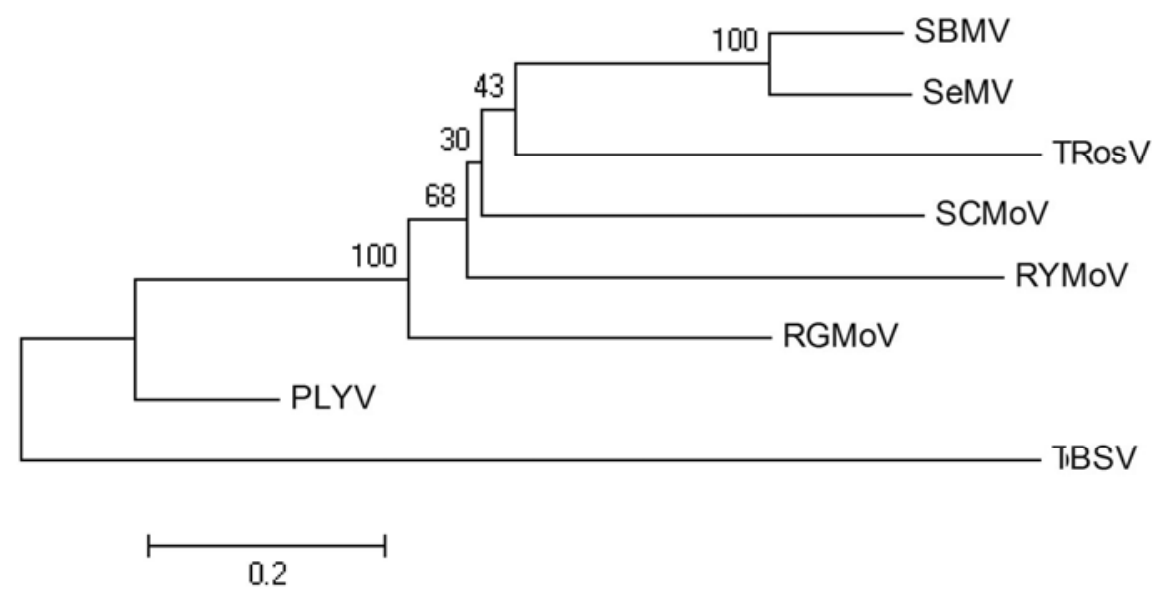

Fig. 5. Phylogenetic tree based on the partial RdRp nucleotide sequences of Papaya lethal yellowing virus Marco isolate $\left(\mathrm{PLYV}_{\mathrm{M}}\right)(\mathrm{GenBank}$ accession no. GU066876), plus additional sequences from Sobemovirus species obtained from GenBank. Horizontal distances are proportional to the genetic distances among isolates. Vertical distances are arbitrary. The number in each branch represents bootstrap values (1,000 replications). Species examined and their GenBank accession numbers included Southern bean mosaic virus São Paulo strain (SBMV, DQ875594), Sesbania mosaic virus (SeMV, AY004291), Turnip rosette virus (TRosV, AY177608), Subterranean clover mottle virus (SCMoV, AY376453), Rice yellow mottle virus (RYMoV, AM883054), and Ryegrass mottle virus (RGMoV, DQ481606). Tomato bushy stunt virus (TBSV, NC001554) was included as the selected out-group.

Table 1. Percentages of similarity among nucleotide sequences of an RNA fragment corresponding to the RdRp gene of Papaya lethal yellow virus isolated from Marco County, Brazil $\left(\mathrm{PLYV}_{\mathrm{M}}\right)$ with members of the genus Sobemovirus

\begin{tabular}{|c|c|c|c|c|c|c|c|c|}
\hline Virus $^{a}$ & PLYV $_{M}$ & TBSV & RGMoV & RYMoV & SBMV & SesMV & SCMoV & TRosV \\
\hline $\operatorname{PLYV}_{M}$ & - & & & & & & & \\
\hline TBSV $^{b}$ & 46 & - & & & & & & \\
\hline RGMoV & 55 & 41 & - & & & & & \\
\hline RYMoV & 51 & 41 & 49 & - & & & & \\
\hline SBMV & 52 & 40 & 49 & 49 & - & & & \\
\hline SesMV & 52 & 41 & 48 & 48 & 72 & - & & \\
\hline SCMoV & 51 & 41 & 48 & 48 & 45 & 50 & - & \\
\hline TRosV & 54 & 41 & 46 & 46 & 41 & 49 & 50 & - \\
\hline
\end{tabular}

${ }^{a} \mathrm{PLYV}_{\mathrm{M}}$, Papaya lethal yellowing virus isolate from Marco County; RGMoV, Ryegrass mottle virus; RYMoV, Rice yellow mottle virus; SBMV, Southern bean mosaic virus; SesMV, Sesbania mosaic virus; SCMoV, Subterranean clover mottle virus; TRosV, Turnip rosette virus.

b TBSV, Tomato bushy stunt virus, genus Tombusvirus, out-group used for phylogenetic comparisons. 
ponent (Fig. 2) was similar to the results obtained by Camarço et al. (5) and Saraiva (31). On the other hand, SBMV has two structural proteins (12).

The serological results confirmed the high sensitivity of indirect ELISA for virus detection in infected tissues. Based on the results, $1.0 \mathrm{ml}$ of the antiserum diluted to 1:16,000 should be sufficient to test more than 140,000 papaya samples, being able to detect the presence of the virus in very low concentration $(1: 512,000$ extract dilution). Viruses of the genus Sobemovirus are typically found in very high concentrations in infected hosts, and their good immunogenic and antigenic properties enable the production of high titer antisera (36). The antiserum produced to $\mathrm{PLYV}_{\mathrm{M}}$ had a titer of 1:1,024,000.

The physical properties determined for PLYV $_{M}$ confirmed the high stability of the virus, considering that only a few plant viruses have a TIP between 75 and $90^{\circ} \mathrm{C}$. The physical properties determined for PLYV $_{M}$ are similar to those found for SBMV (12).

The detection of $\mathrm{PLYV}_{\mathrm{M}}$ in dried roots and leaves of infected papaya after a period of 120 days confirmed the high stability of the virus and its viability in nonliving plant tissues over a long period of time. The serological virus detection in dried tissues indicated that the PLYV coat protein is very stable and the virus can be easily detected in dried and dead tissues. The results also confirmed that the high stability of the virus particles could contribute to its survival in the field and could facilitate its dissemination by human actions, which could explain its dispersion without a biological vector $(5,20,21,32)$. For this reason, it is important and necessary to practice roguing and elimination of old abandoned orchards as a preventive control measure to reduce the source of virus in the field (20). The difference observed between the LIV (60 days) found for PLYV $_{M}$ and its survival in infected dried tissue (120 days) could be explained by the environment in which the virus particles were maintained. The dried tissue had no effect of enzymes, which permitted a longer period of surviving for virus infectivity. On the other hand, in the plant sap, virus particles were submitted to enzymatic actions, which could reduce the time of virus survival. Considering that the high PLYV $_{M}$ stability in dried eradicated tissues from infected plants could interfere with the use of roguing for virus eradication in the field, the solarization demonstrated to be an efficient agricultural practices for virus inactivation (Fig. 3).

The virus genome characterization indicated that the RdRp cistron consisted of $927 \mathrm{nt}$ and the CP cistron was $497 \mathrm{nt}$ in size, with an overlapping region of $326 \mathrm{nt}$. The RdRp has two conserved motifs usually found in viral RdRp: GDD and FCSH. The CP has the conserved motif
MPYTVGTWLRGVASNWSK found in all members of the genus Sobemovirus. Although previous studies based on $\mathrm{CP}$ and RNA sizes and CP amino acid sequence suggested that PLYV could be included in the genus Tombusvirus (35), further studies $(7,34)$ and the present data (Table 1, Fig. 5) indicated a higher similarity of PLYV with members of the genus Sobemovirus. More detailed molecular studies are being developed with the virus genome for its complete genome sequence determination to elucidate the correct PLYV taxonomic position.

\section{ACKNOWLEDGMENTS}

We thank the Foundation for Scientific and Technological Development of the State of Ceará (FUNCAP) and the National Council for Scientific and Technological Development (CNPq) of Brazil for their funding to conduct this research and for the first and second authors' fellowships.

\section{LITERATURE CITED}

1. Almeida, A. M. R., and de Carvalho, S. L. C. 1978. Ocorrência do vírus do mosaico do mamoeiro no estado do Paraná. Fitopatol. Bras. 3:220-225.

2. Amaral, P. P., Resende, R. O., and Souza Junior, M. T. 2006. Papaya lethal yellowing (PLYV) infects Vasconcellea cauliflora. Fitopatol. Bras. 31:517.

3. Badillo, V. M. 1993. Caricaceae. Segundo Esquema. Revista de la Facultad de Agronomía de la Universidad Central, Alcance 43. Maracay, Venezuela.

4. Barbosa, F. R., and Paguio, D. R. 1982. Vírus da Mancha Anelar do Mamoeiro: Incidência e Efeito na produção do mamoeiro. Fitopatol. Bras. 7:365-373.

5. Camarço, R. F. E. A., Lima, J. A. A., and PioRibeiro, G. 1998. Transmissão e presença em solo do "Papaya lethal yellowing virus". Fitopatol. Bras. 23:453-458.

6. Camarço, R. F. E. A., Lima, J. A. A., PioRibeiro, G., and Andrade, G. P. 1996. Ocorrência do "papaya lethal yellowing virus" no município de Santa Rita, Estado da Paraíba. (Abstr.) Fitopatol. Bras. 29:423.

7. Daltro, C. B., Fiuzza, A., and Andrade, E. C. 2009. Estudo da variabilidade genética entre isolados do vírus do amarelo letal do mamoeiro (Papaya lethal yellowing virus PLYV). Accessed 30 Nov. 2009. http://www. cnpmf.embrapa.br/publicacoes/jornada/resumos/ Resumo_CleidianeBD_EduardoCA_PLYV_ rev_JR_ED_.pdf

8. Fauquet, C. M., Mayo, M. A., Maniloff, J., Desselberger, U., and Ball, L. A., eds. 2005. Virus Taxonomy - Eighth Report of the International Committee on Taxonomy of Viruses. Elsevier Academic Press, San Diego, CA.

9. Ferreira, F. R., Dantas, J. L. L., Martins, V. A., and Noronha, S. E. 2005. Ocorrência e distribuição de Vasconcella e Jacaratia, parentes silvestres de Mamão, no Sul e Centro-oeste do Brasil. Papaya Brasil. Primeiro Simpósio do Papaya brasileiro/INCAPER - Annals:293-297.

10. Hiebert, E., and McDonald, J. G. 1976. Capsid protein heterogeneity in turnip mosaic virus. Virology 70:144-150.

11. IBGE - Institudo Brasileiro de Geografia e Estatistica. 2008. Accessed 20 nov. 2008. http://ibge.gov.br

12. ICTVdB Management. 2006. 00.067.0.01.001. Southern bean mosaic virus. In: ICTVdB - The Universal Virus Database, version 4. C. Büchen-Osmond, ed. Columbia University, New York.

13. Kitajima, E. W., Oliveira, F. C., Pinheiro, C. R. S., Soares, L. M., Pinheiro, K., Madeira, M.
C., and Chagas, M. 1992. Amarelo letal do mamoeiro solo no estado do Rio Grande do Norte. Fitopatol. Bras. 17:282-285.

14. Kitajima, E. W., Rezende, J. A. M., Veja, J., and Oliveira, F. C. 1992. Confirmada identidade do vírus isométrico encontrado em mamoais do Rio Grande do Norte como sendo o do amarelo letal do mamoeiro solo. Fitopatol. Bras. 17:336-338.

15. Kumar, S., Dudley, J., Nei, M., and Tamura, K. 2008. MEGA: A biologist-centric software for evolutionary analysis of DNA and protein sequences. Briefings Bioinform. 9:299-306.

16. Lane, L. 1992. A general method for detecting plant viruses. Pages 1-15 in: Plant Diseases of Viral, Viroid, Mycoplasma and Uncertain Origin. K. Maramorosch, ed. Oxford and IBH Publishing, New Delhi.

17. Lima, J. A. A., and Gomes, M. N. S. 1975. Identificação de "papaya ringspot virus" no Ceará. Fitossanidade 1:56-59.

18. Lima, J. A. A., Lima, A. R. T., and Marques, M. A. L. 1994. Purificação e caracterização sorológica de um isolado do vírus do amarelo letal do mamoeiro solo obtido no Ceará. (Abstr.) Fitopatol. Bras. 19:437.

19. Lima, J. A. A., and Santos, C. D. G. 1991. Isolamento de possível estirpe do vírus do amarelo letal do mamoeiro no Ceará. (Abstr.) Fitopatol. Bras. 26:27.

20. Lima, R. C. A., and Lima, J. A. A. 2002. Viroses em mamoeiro e alternativas de controle/ Roberto Caracas de Araújo Lima. Fortaleza: Secretaria da Agricultura Irrigada.

21. Lima, R. C. A., Lima, J. A. A., Souza, M. T., Jr., Pio-Ribeiro, G., and Andrade, G. P. 2001 Etiologia e estratégias de controle de viroses do mamoeiro no Brasil. Fitopatol. Bras. 26:689-702.

22. Loreto, T. J. G., Vital, A. F., and Rezende, J. A. M. 1983. Ocorrência de um amarelo letal do mamoeiro solo no estado de Pernambuco. O Biológico 49:275-279.

23. Marciel-Zambolim, E., Kunieda-Alonso, S., Matsuoka, K., Carvalho, M. G., and Zerbini, F M. 2003. Purification and some properties of Papaya meleira virus, a novel virus infecting papayas in Brazil. Plant Pathol. 52:389-394.

24. Mowat, W. P., and Dawson, S. 1987. Detection of plant viruses by ELISA using crude sap extracts and unfractionated antisera. J. Virol. Methods 15:233-247.

25. Nordam, D. 1973. Identification of plant viruses. Pages 88-102 in: Methods and Experiments. Pudoc, Wageningen, Netherlands, Centre for Agricultural Publishing and Documentation.

26. Oliveira, C. R. B., Ribeiro, S. G., and Kitajima, E. W. 1989. Purificação e propriedades químicas do vírus do amarelecimento letal do mamoeiro isolado do Rio Grande do Norte. Fitopatol. Bras. 14:114.

27. Purcifull, D. E., and Batchelor, D. L. 1977. Immudiffusion tests with sodium dodecyl sulfate (SDS) - treated plant viruses and plant virus inclusions. Univ. Florida Agric. Exp. Stn. Bull. 788.

28. Purcifull, D. E., Edwardson, J., Hiebert, E., and Gonsalves, D. 1984. Papaya ringspot virus. Descriptions of Plant Viruses. Survey: 292. CMI/AAB, Kew, Surrey, England.

29. Ramos, N. F., Nascimento, A. K. Q., Goncalves, M. F. B., and Lima, J. A. A. 2008. Presença dos vírus da mancha anelar e do amarelo letal em frutos de mamoeiro comercializados. Trop. Plant Pathol. 33:449-452.

30. Santos, H. P., Barbosa, C. J., and Nickel, O. 2003. Doenças Do Mamoeiro. Pages 391-434 in: Doenças de fruteiras tropicais de interesse agroindustrial. F. das C. O. Freire, J. E. Cardoso, and F. M. P. Viana, eds. Embrapa Informação Tecnológica; Fortaleza: Embrapa Agroindústria Tropical, Brasília, DF.

31. Saraiva, A. C. M. 2004. Estudo da transmissão 
e da sobrevivência do vírus do amarelo letal do mamoeiro. M.S. thesis. Federal University of Ceará, Fortaleza.

32. Saraiva, A. C. M., Paiva, W. O., Rabelo Filho, F. A. C., and Lima, J. A. A. 2006. Transmissão por mãos contaminada e ausência de transmissão embrionária do vírus do amarelo letal do mamoeiro. Fitopatol. Bras. 31:79-83.

33. Silva, A. M. R. 1996. "Papaya lethal yellowing virus": Caracterização biológica e molecular. M.S. thesis. Federal University of Brasilia, Brasilia.

34. Silva, A. M. R., Kitajima, E. W., and Resende, R. O. 2000. Nucleotide and amino acid analy- sis of the polymerase and the coat protein genes of the papaya lethal yellowing virus. (Abstr.) Virus Reviews and Research 11:196.

35. Silva, A. M. R., Kitajima, E. W., Souza, M. V., and Resende, R. 1997. Papaya lethal yellowing virus: A possible member of the Tombusvirus genus. Fitopatol. Bras. 22:529-534.

36. Tamm, T., and Truve, E. 2000. Sobemoviruses. J. Virol. 74: 6231-6241.

37. Tremaine, J. H., and Hamilton, R. I. 1983. Southern bean mosaic virus. Descriptions of Plant Viruses. 274. CMI/AAB, Kew, Surrey, England.

38. Vega, J., Bezerra, J. L., and Rezende, M. L. V.
1988. Detecção do vírus do amarelo letal do mamoeiro solo no estado da Bahia através de microscopia eletrônica. (Abstr.) Fitopatol. Bras. 21:147.

39. Ventura, J. A., Costa, H., and Tatagiba, J. S. 2004. Papaya diseases and integrated control. In: Naqvi. (Org.) Diseases of fruits and vegetables: Diagnosis and management. Kluwer Academic Publishers, Dordrecht, Netherlands. 2:201-268.

40. Weber, K., and Osborn, M. 1969. The reliability of molecular weight determinations by dodecyl sulfate-polyacrylamide gel electrophoresis. J. Biol. Chem. 244:4406-4412. 